\title{
Diabetes-related changes in contractile responses of stomach fundus to endothelin-1 in streptozotocin- induced diabetic rats
}

\author{
Kazuki ENDO ${ }^{1}$, Takayuki MATSUMOTO ${ }^{1}$, Tsuneo KOBAYASHI $^{1}$, \\ Yutaka KASUYA $^{1}$ and Katsuo KAMATA ${ }^{1}$ \\ ${ }^{1}$ Department of Physiology and Morphology, Institute of Medicinal Chemistry, Hoshi \\ University, Shinagawa-ku, Tokyo 132-8501, Japan
}

\begin{abstract}
The contractile response of the stomach fundus to endothelin-1 (ET-1) was examined in streptozotocin (STZ)-induced diabetic rats. In STZ-diabetic rats (versus age-matched control rats) (a) ET-1 caused a longer-lasting contraction of stomach fundus strips, and (b) in the dose-response curve, the ET-1-induced contraction was significantly greater for a given concentration $\left(3 \times 10^{-7}\right.$ to $\left.10^{-7} \mathrm{M}\right)$. Although repeated application of ET-1 led to desensitization, the desensitization was less pronounced in STZ-diabetic rats than in the controls. The density of the binding sites for [ $\left.{ }^{125} \mathrm{I}\right]-\mathrm{ET}-1$ was increased in the diabetic stomach fundus (versus the controls), but Kd values were similar between the two groups. The $\mathrm{ET}_{\mathrm{B}}$ receptor mRNA expression level was significantly increased in the diabetic stomach fundus. These results suggest that the diabetes-related enhancement of the ET-1-induced contraction of the stomach fundus may be due to an increase in the $\mathrm{ET}_{\mathrm{B}}$ receptor population.
\end{abstract}

Key words: contraction, desensitization, diabetes, endothelin, stomach

\section{Introduction}

Endothelin-1 (ET-1), originally isolated by Yanagisawa et al. (1988) from porcine aortic endothelial cells, is the most powerful endogenous vasoconstrictor agent known, and moreover it has been found to be a powerful mitogen for vascular smooth muscle cells (Goto et al., 1996; Miyauchi and Masaki, 1999; Masaki, 2004). It has been reported that endothelins are produced in the gut (Ota et al., 1991), and that their receptors are present within the stomach and intestine (Takahashi et al., 1990b). In rat isolated stomach strip, ET-1 causes dose-dependent contractions (Wallace et al., 1989b; Fulginiti et al., 1993; Shimomura et al., 1994; Allcock et al., 1995). The functional effects of ET-1 are mediated through at least two distinct subtypes of receptors, the $\mathrm{ET}_{\mathrm{A}}$ and $\mathrm{ET}_{\mathrm{B}}$ receptors (Goto et al., 1996; Miyauchi and Masaki, 1999; Masaki, 
2004). In isolated smooth muscle cells from guinea pig stomach, two ET receptors are present, but whereas the $\mathrm{ET}_{\mathrm{A}}$ receptor mediates contraction, the $\mathrm{ET}_{\mathrm{B}}$ receptor is involved in neither contraction nor relaxation (Kitsukawa et al., 1994). Also, functional studies demonstrated that ET-1 and the $\mathrm{ET}_{\mathrm{B}}$ receptor-selective agonist sarafotoxin S6c elicit contraction of the rat fundic strip via high affinity $\mathrm{ET}_{\mathrm{B}}$ receptors (Gray et al., 1995). The above suggests that ET-1 may play an important role in regulating gastric motility, although the physiological role played by ET-1 in stomach contraction is still not understood.

Diabetes mellitus is a metabolic disease affecting every organ system in the body, including the gastrointestinal tract (Katz and Spiro, 1966). Indeed, diabetic gastroparesis is a well-known complication of long-standing diabetes (Keshavarzian et al., 1987). Diabetic gastroparesis is a condition comprising a decrease in fundic and antral motor activity (Fox and Behar, 1980; Keshavarzian et al., 1987), a reduction in, or lack of, the interdigestive migrating motor complex (Fox and Behar, 1980), gastric dysrhythmias (Koch et al., 1989), and "pylorospasms" (Mearin et $a l .$, 1986). The etiology of diabetic gastroparesis is still not fully established, but important factors seem to be autonomic neuropathy (Keshavarzian et al., 1987), acute hyperglycemia (Rayner et al., 2001), and abnormalities of gut hormones and neurotransmitters, such as motilin (Achem-Karam et al., 1985), gastrin (Feldman et al., 1979), and nitric oxide (Bult et al., 1990). Other factors that may modulate gastrointestinal motility include thyroid function (Holdsworth and Besser, 1968), gastric acid secretion (Bortolotti and Barbara, 1988), and Helicobacter pylori infection (Perri et al., 1996).

Interestingly, plasma ET-1 levels are known to be increased in the diabetic state (Takahashi et al., 1990a; Makino and Kamata, 1998a,b, 2000, 2002; Makino et al., 2001; Kanie and Kamata, 2002; Kanie et al., 2003), and moreover the plasma concentration of big endothelin-1, the precursor of ET-1, is elevated in patients with diabetes mellitus (Tsunoda et al., 1991). Thus, although ET-1 may also contribute to the normal maintenance of vascular tone, a pathogenetic role is implied by its overproduction in patients with diabetes (Takahashi et al., 1990a). Indeed, the vasomotor response to ET-1 is altered in several vessels in the diabetic state (Makino and Kamata, 1998, 2000; Makino et al., 2001; Khan and Chakrabarti, 2003; Matsumoto et al., 2004a). In contrast, to our knowledge there are no reports concerning any change in the contractile response of the stomach fundus to ET-1 in diabetic rats, although plasma ET-1 is known to be elevated in such animals.

The aims of the present study were look for evidence of (1) changes in the contractile response of the stomach fundus to ET-1 in STZ-induced diabetic rats and (2) changes in the density of ET-1 receptors in these rats.

\section{Materials and Methods}

\section{Animals and experimental design}

Male Wistar rats ( 8 wk old and 180-230 g body weight) received a single injection via the tail vein of STZ $65 \mathrm{mg} / \mathrm{kg}$ dissolved in a citrate buffer. Age-matched control rats were injected with the buffer alone. Food and water were given ad libitum. This study was conducted in accordance with the Guide for the Care and Use of Laboratory Animals adopted by the 
Committee on the Care and Use of Laboratory Animals of Hoshi University (which is accredited by the Ministry of Education, Culture, Sports, Science and Technology, Japan).

\section{Measurement of plasma glucose}

Twelve weeks after the injection of STZ or buffer, plasma glucose was determined using a commercially available enzyme kit (Wako Chemical Company, Osaka, Japan), which made use of the $O$-toluidine method.

\section{Preparation of tissues}

Male Wistar rats were anesthetized with sodium pentobarbital (50 mg/kg, i.p.), then killed by decapitation. The stomach was excised, and fundus strip preparations of approximately 20 $\mathrm{mm}$ length and $2 \mathrm{~mm}$ width were made essentially by our published methods (Kamata $e$ t al., 1988, 1993). Each strip was cut out along the line of the longitudinal muscle, and the mucous layer was completely removed to avoid reflex activity. The fundus strips were suspended in a 10 $\mathrm{ml}$ organ bath containing modified Krebs Ringer solution at $37^{\circ} \mathrm{C}$, aerated with $95 \% \mathrm{O}_{2}$ and $5 \%$ $\mathrm{CO}_{2}$. The tension loaded onto each strip was $1.0 \mathrm{~g}$. Contractions were recorded isotonically using an isotonic transducer connected to an ink-writing recorder (Nihon Kohden, Tokyo, Japan). The composition of the modified Krebs Ringer solution (mM) was as follows: $\mathrm{NaCl} 120$; $\mathrm{KCl}$ 4.7; $\mathrm{CaCl}_{2} 2.0 ; \mathrm{MgCl}_{2}$ 1.2; $\mathrm{NaHCO}_{3} 25 ; \mathrm{KH}_{2} \mathrm{PO}_{4}$ 1.2; and glucose 14. The fundus strips were left in the above conditions for $30 \mathrm{~min}$ at $37^{\circ} \mathrm{C}$. When ET-1 was to be applied to the strip, the tissue was preincubated with $10^{-6} \mathrm{M}$ atropine and $10^{-6} \mathrm{M}$ guanethidine (to avoid any cholinergic or adrenergic effects being induced throughout the experiment.

\section{Receptor-binding assay}

For each group (STZ-diabetic or age-matched control rats) a single membrane preparation was obtained from a total of 70 stomach fundus strips. The strips were homogenized in $10 \mathrm{vol}$ (w/v) of ice-cold buffer A (50 mM Tris- $\mathrm{HCl}, \mathrm{pH} 7.4$. containing $120 \mathrm{mM} \mathrm{NaCl}$ and $5 \mathrm{mM} \mathrm{KCl}$ ) using a Polytron (Kinematica) set at position 7 for $10 \mathrm{sec}$, three times. The homogenate was incubated on ice in the presence of $300 \mathrm{mM} \mathrm{KCl}$ and $10 \mathrm{mM}$ EDTA for $30 \mathrm{~min}$ with intermittent mixing, then centrifuged at $50,000 \mathrm{~g}$ for $15 \mathrm{~min}$ at $4^{\circ} \mathrm{C}$. The pellet was resuspended in $20 \mathrm{vol}$ of ice-cold buffer B (50 mM Tris-HCl, pH 7.4) using a Polytron at position 7 for 10 sec, then centrifuged again as above. The washing procedure was repeated twice more, and the final pellet was resuspended in $60 \mathrm{vol}$ of buffer B. For the binding experiments, the reaction was initiated by adding $400 \mu \mathrm{l}$ of the freshly prepared membrane preparation to $100 \mu \mathrm{l}$ of $50 \mathrm{mM}$ Tris- $\mathrm{HCl}$ ( $\mathrm{pH} 7.4$ ) containing $0.02 \%$ bovine serum albumin, $4 \mu \mathrm{g} / \mathrm{ml}$ chymostatin, $4 \mu \mathrm{g} / \mathrm{ml}$ leupeptin, $40 \mu \mathrm{g} / \mathrm{ml}$ bacitracin, and commercially obtained ${ }^{125}$ I-labeled ET-1 samples. This was left at $20^{\circ} \mathrm{C}$ for $30 \mathrm{~min}$, and the reaction was then terminated by adding $5 \mathrm{ml}$ of ice-cold buffer A to each tube. The contents of each tube were filtered immediately through Whatman GF/C glass fiber filters (pre-treated with $0.1 \%$ polyethyleneimine in water for more than $3 \mathrm{~h}$ to reduce the non-specific adsorption of ${ }^{125}$ I-labeled ET-1 to the filters). Each filter was then quickly washed once with $20 \mathrm{ml}$ of ice-cold buffer A, and the radioactivity was determined using a $\gamma$ counter. Non-specific binding was determined using $1 \mu \mathrm{M}$ ET-1. The protein content of the 
Table 1 Oligonucleotide primer sequences for ET-1 receptors and GAPDH, together with PCR protocols

\begin{tabular}{lccc}
\hline Target gene & PCR Primer Sequences & PCR Protocols & Product Size \\
\hline ET $_{\mathrm{A}}$ receptor & 5'-ATCGCTGACAATGCTGAGAG-3’ & $94^{\circ} \mathrm{C} / 60 \mathrm{~s}$ & $226 \mathrm{bp}$ \\
& 5'-CCACGATGAAAATGGTACAG-3’ & $54^{\circ} \mathrm{C} / 60 \mathrm{~s}$ & \\
& & $72^{\circ} \mathrm{C} / 60 \mathrm{~s}$ & \\
& & $26 \mathrm{cycles}$ & \\
ET $_{\mathrm{B}}$ receptor & 5'-AGCTGGTGCCCTTCATACA-3' & $94^{\circ} \mathrm{C} / 60 \mathrm{~s}$ & $447 \mathrm{bp}$ \\
& 5'-TCTTGGCCACTTCTCGTCT-3’ & $54^{\circ} \mathrm{C} / 60 \mathrm{~s}$ & \\
& & $72^{\circ} \mathrm{C} / 60 \mathrm{~s}$ & \\
GAPDH & 5'-TCCCTCAAGATTGTCAGCAA-3’ & $94^{\circ} \mathrm{C} / 60 \mathrm{~s}$ & $308 \mathrm{bp}$ \\
& 5'-AGATCCACAACGGATACATT-3' & $54^{\circ} \mathrm{C} / 60 \mathrm{~s}$ & \\
& & $72^{\circ} \mathrm{C} / 60 \mathrm{~s}$ & \\
& & $21 \mathrm{cycles}$ & \\
& & &
\end{tabular}

membrane suspension was measured by the method of Lowry et al. (1951) using bovine serum albumin as standard.

Measurement of the expressions of the mRNAs for ET receptors (using RT-PCR)

RNA was isolated by the guanidinium method (Chomczynski and Sacchi, 1987). Briefly, rat stomach fundus strips were carefully isolated (as described above). They were then homogenized in RNA buffer, and the RNA was quantified by ultraviolet-absorbance spectrophotometry. For the RT-PCR analysis, first-strand cDNA was synthesized from total RNA using Oligo (dT) 20 and a ThermoScript ${ }^{\mathrm{TM}}$ RT-PCR System (Invitrogen Corp., Carlsbad, CA, U.S.A.). All primers were synthesized by Sigma-Genosys (St. Louis, MO, U.S.A.). Individual sequences, PCR conditions, and product sizes are shown in Table 1. To ensure that we were within the exponential phase of the semi-quantitative PCR reaction (Wang et al., 1989), the appropriate number of cycles was newly established for each set of samples. Control PCR reactions, in which the RT was omitted, were run simultaneously to check for successful removal of the genomic DNA. The PCR products so obtained were analyzed on ethidiumbromide-stained agarose (1.5\%) gels, and quantified by scanning densitometry, with the amount of each product being normalized with respect to the amount of GAPDH product.

\section{Drugs}

The following drugs were used in the present study: bacitracin, chymostatin, bovine serum albumin (Fraction V), leupeptin, and streptozotocin (Sigma St. Louis, MO, U.S.A); endothelin-1 (Peptide Institute Inc., Osaka, Japan); ${ }^{125}$ I-labeled ET-1 (Amersham International plc., Buckinghamshire, U.K.); and polyethyleneimine (Tokyo Kasei Pharmaceuticals, Tokyo, Japan). All concentrations are expressed as the final molar concentration of the base in the organ bath. ${ }^{125}$ I-labeled ET-1 was stored under liquid $\mathrm{N}_{2}$ until needed for experimentation, when it was aliquoted out and stored at $-20^{\circ} \mathrm{C}$. 


\section{Statistical analysis}

The contractile force developed by fundus strips from control and diabetic rats is expressed in $\mathrm{g}$ tension/mg tissue, the data being given as the mean \pm S.E.M. When appropriate, statistical differences were assessed using Dunnett's test for multiple comparisons after a one-way analysis of variance, a probability level of $P<0.05$ being regarded as significant. Statistical comparisons between concentration-response curves were assessed using a two-way ANOVA with a Bonferroni correction performed post-hoc to correct for multiple comparisons; again, $P<0.05$ was considered significant.

\section{Results}

Change in body weight and plasma glucose

In accord with our previous reports (Matsumoto et al., 2003, 2004b), at the time of the experiment (a) all STZ-treated rats exhibited hyperglycemia, their blood glucose concentrations (567.0 $\pm 13.7 \mathrm{mg} / \mathrm{dl}, \mathrm{n}=15)$ being significantly higher than those of the age-matched nondiabetic control rats $[118.8 \pm 2.8 \mathrm{mg} / \mathrm{dl}, \mathrm{n}=15(P<0.001)]$ and $(\mathrm{b})$ the body weights of the diabetic rats $(252.7 \pm 8.0 \mathrm{~g}, \mathrm{n}=15)$ were significantly lower than those of the age-matched control rats [474.4 $\pm 6.1 \mathrm{~g}, \mathrm{n}=15(P<0.001)]$.

\section{Contractile responses to ET-1}

The contractile responses ( $\mathrm{g}$ tension/mg tissue) induced in stomach fundus strips from control and diabetic rats by ET-1 and the calcium-channel activator, BayK 8644, are shown in Fig. 1. Although there was a significant increase in the maximal contractile response to ET-1 in STZ-diabetic rats (versus the control rats) (Fig. 1A), the Bay K 8644-induced contraction was almost the same between the two groups (Fig. 1B). A single administration of ET-1 $\left(10^{-7} \mathrm{M}\right)$ induced a longer-lasting contraction in STZ-diabetic rats than in the age-matched controls (Fig. 2). The fundus strips were exposed to $10^{-7} \mathrm{M} \mathrm{ET}-1$ for $20 \mathrm{~min}$. After washout, at an interval of 20-30 min, this procedure was repeated three times in the same preparations. As shown in Fig. $3 \mathrm{~A}$, repeated application of ET-1 $\left(10^{-7} \mathrm{M}\right)$ led to a marked desensitization in the age-matched control rats, but the desensitization was much less pronounced in STZ-diabetic rats. Quantitative summary data are shown in Fig. 3B.

\section{Receptor binding assay}

The specific binding of ${ }^{125}$-labeled ET-1 was saturable with increasing concentrations of the ligand, and a Scatchard analysis of the saturation curve indicated a single binding site. After 12 weeks of diabetes (i.e., 12 weeks after the STZ injection): (a) the receptor density $\left(\mathrm{B}_{\max }\right)$ was greater than in the age-matched controls, when expressed as the number of receptors per $\mathrm{mg}$ protein (Table 2), but (b) the Kd values were similar between the two groups of rats (Table 2).

\section{Expressions of $m R N A$ for $E T$ receptors}

Using RT-PCR analysis on the total RNA isolated from the stomach fundus, we found the following. The expression of GAPDH mRNA showed no difference between the diabetic group 


\section{A}
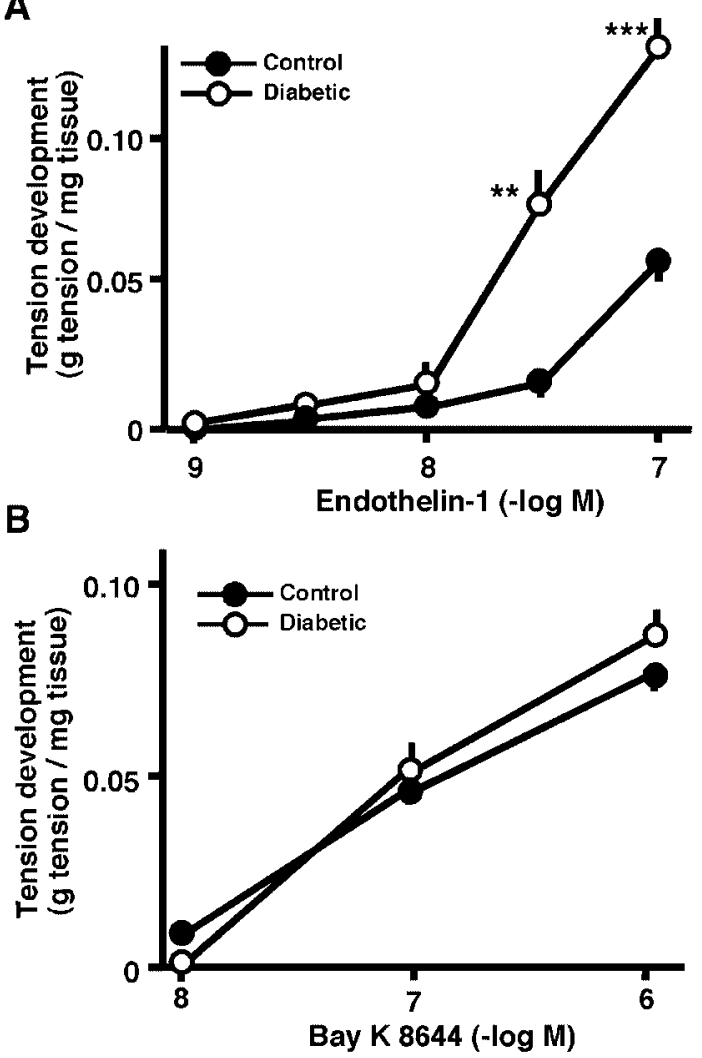

Fig. 1. Concentration-response curves for ET-1- (A) and Bay K 8644- (B) induced contractions in stomach fundus stips from age-matched controls and STZ-induced diabetic rats. Each data-point represents the mean \pm S.E.M. of 10 (A) or 6 (B) experiments, the SE mean being included only when it exceeds the dimension of the symbol used. ${ }^{* *} P<0.01,{ }^{* \star *} P<0.001$, vs. control.

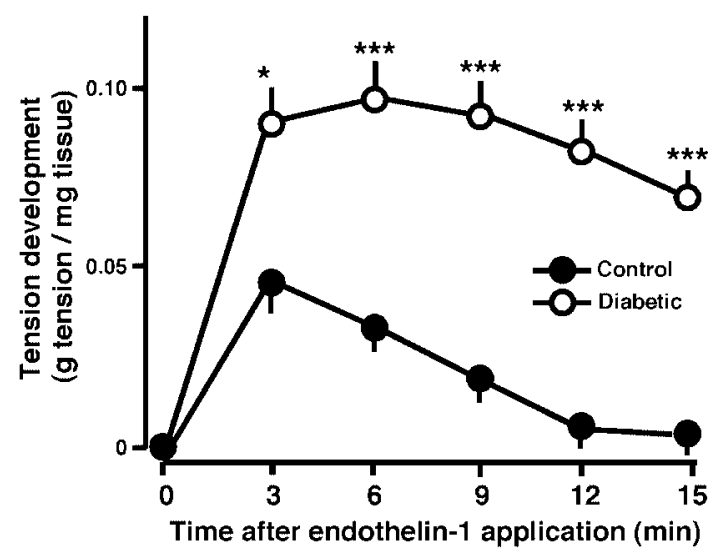

Fig. 2. Time-course of changes in contractile response to ET-1 $\left(10^{-7} \mathrm{M}\right)$ in stomach fundus stips from age-matched control $(n=6)$ and diabetic $(n=6)$ rats. Each data-point represents the mean \pm S.E.M. of 6 experiments. ${ }^{\star} P<0.05$, ${ }^{\star *}{ }^{*} P<0.001$, vs. control. 
A
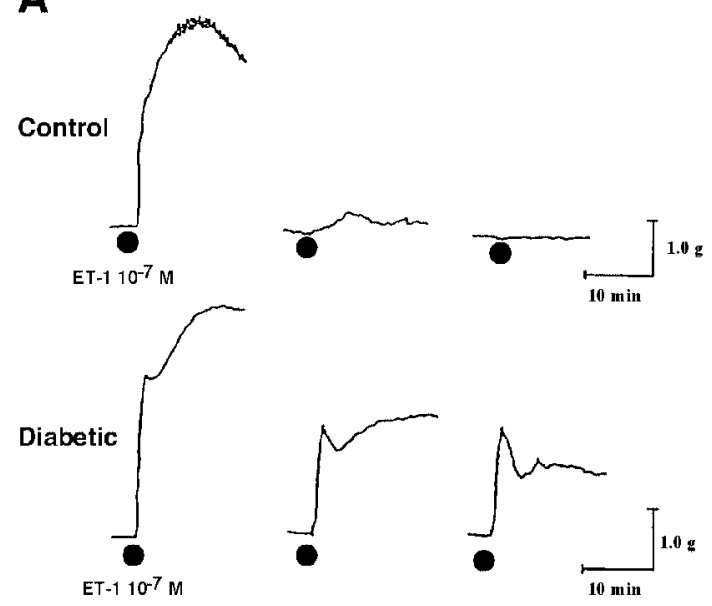

First Second Third

B

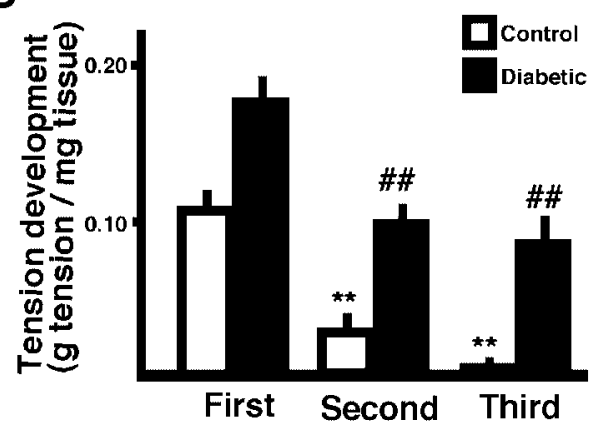

Fig. 3. Changes in ET-1 response upon repeated application in stomach fundus strips from age-matched control and diabetic rats. The fundus strips were exposed to $10^{-7} \mathrm{M}$ ET1 for $20 \mathrm{~min}$. After washout, at an interval of 20-30 min, this procedure was repeated three times in the same preparations. (A) Representative traces showing the ET-1 $\left(10^{-7} \mathrm{M}\right)$-induced contraction in strips from age-matched control (upper) and diabetic (lower) rats. (B) Peak contractile response to repeatedly applied (first, second, third) ET-1 $\left(10^{-7} \mathrm{M}\right)$ in strips from age-matched control $(n=6)$ and diabetic $(n=6)$ rats. Each column represents the mean \pm S.E.M. of 6 experiments. ${ }^{* \star} P<0.01$ vs. "First" control, ${ }^{\#} P<0.01$, vs. "First" diabetic.

and the age-matched control group, but the mRNA expression for the $\mathrm{ET}_{\mathrm{B}}$ receptor, but not for the $\mathrm{ET}_{\mathrm{A}}$ receptor, was significantly greater in the diabetic rats than in the age-matched controls (Fig. 4).

\section{Discussion}

The main conclusion to be drawn from the present study is that the contractile response of the stomach fundus to ET-1 was increased in STZ-induced diabetic rats, a change that may be due to an increased density of the $\mathrm{ET}_{\mathrm{B}}$ receptors for ET-1. 
Table $2{ }^{125}$ I-Endothelin-1 binding assay in stomach fundus strips from controls and streptozotocin-induced diabetic rats

\begin{tabular}{ccc}
\hline Experimental groups & $\begin{array}{c}\text { Bmax } \\
(\mathrm{fmol} / \mathrm{mg} \text { protein })\end{array}$ & $\begin{array}{c}\mathrm{Kd} \\
(\mathrm{nM})\end{array}$ \\
\hline Control & $721.4 \pm 60.7$ & $200.1 \pm 17.8$ \\
Diabetic & $1818.7 \pm 170.8^{* *}$ & $164.7 \pm 24.2$
\end{tabular}

$\overline{\mathrm{Bmax}}$ and Kd values were calculated by Scatchard plot analysis of binding data. Values are expressed as mean \pm S.E.M. for 4 separate experiments. ${ }^{*} P<0.01$ vs. control.

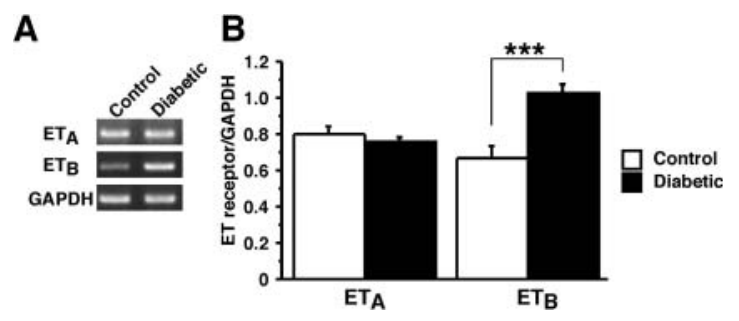

Fig. 4. RT-PCR assay of expressions of mRNAs for ET receptors in strips of stomach fundus from age-matched controls and STZ-diabetic rats. (A) Expressions of mRNAs for $\mathrm{ET}_{\mathrm{A}}$ and $\mathrm{ET}_{\mathrm{B}}$ receptors by RT-PCR. (B) Quantitative analysis by scanning densitometry. Values are each the mean \pm S.E.M. of six determinations (target gene/GAPDH). The RT-PCR assay was performed as described in Materials and Methods. Each total RNA preparation $(3.0 \mu \mathrm{g})$ was reverse-transcribed, and the cDNA product was PCRamplified using various primers, several cycles being employed. A portion of the PCR reaction product was electrophoresed on a $1.5 \%$ agarose gel containing ethiodium bromide.

ET-1 is involved in the contraction of a variety of tissues, including gastric smooth muscle and vascular smooth muscle (Kitsukawa et al., 1994; Allcock et al., 1995; Goto et al., 1996; Miyauchi and Masaki, 1999) and it is thought to act through two receptors, $\mathrm{ET}_{\mathrm{A}}$ and $\mathrm{ET}_{\mathrm{B}}$ receptors (Goto et al., 1996; Miyauchi and Masaki, 1999). Both of these receptor-subtypes may be coupled to phospholipase C (PLC) via a GTP-binding protein. Activation of PLC induces phosphatidylinositol hydrolysis, rapid formation of 1, 4, 5-inositol triphosphate $\left(\mathrm{IP}_{3}\right)$, and accumulation of 1,2-diacylglycerol (DG). $\mathrm{IP}_{3}$ stimulates the release of $\mathrm{Ca}^{2+}$ from the intracellular stores, including the endoplasmic reticulum. For example, application of ET-1 to arterial smooth muscle cells causes a rapid, transient increase in the intracellular $\mathrm{Ca}^{2+}$ concentration $\left(\left[\mathrm{Ca}^{2+}\right]_{\mathrm{i}}\right)$ followed by a sustained increase in $\left[\mathrm{Ca}^{2+}\right]_{\mathrm{i}}$ (Simonson and Dunn, 1990). The initial transient $\left[\mathrm{Ca}^{2+}\right]_{\mathrm{i}}$ response is not dependent on the presence of extracellular $\mathrm{Ca}^{2+}$, and is the result of $\mathrm{IP}_{3-}$ induced mobilization of $\mathrm{Ca}^{2+}$ from the intracellular stores. In contrast, the sustained increase in $\left[\mathrm{Ca}^{2+}\right]_{i}$ appears to be due to an influx of extracellular $\mathrm{Ca}^{2+}$ through either dihydropyridinesensitive voltage-dependent L-type $\mathrm{Ca}^{2+}$ channels (LTCC) (Goto et al., 1989) or receptoroperated (nonselective) cation channels that are insensitive to dihydropyridine (Iwamuro et al., 1998). In the present study, ET-1 induced a dose-dependent contraction in stomach fundus strips and this contractile response was much greater in the STZ-diabetic group than in the control group (Fig. 1A). In contrast, we found no diabetes-related change (a) in the contractile 
response of the fundus to the LTCC activator, Bay K8644 (Fig. 1B) or (b) in the $\mathrm{Ca}^{2+}$-induced contractile response in strips preincubated with an extracellular bathing solution containing zero calcium (data not shown). This suggests that the increase in the ET-1-induced contractile response in the diabetic group was not due to any alteration in $\mathrm{Ca}^{2+}$ influx via $\mathrm{Ca}^{2+}$-channels.

Prolonged and repeated exposure to agonist reduces the responsiveness of G-proteincoupled receptors (Ferguson, 2001). Substantial experimental evidence has divided this reduced function into three separate, but related, receptor events: 1) desensitization, 2) internalization, and 3) downregulation (Bunemann and Hosey, 1999; Ferguson, 2001; Ueda et $a l .$, 2001). Like many $G$ protein-coupled receptor signaling systems (Ferguson, 2001), the receptor/Gq/PLC system(s) activated by the $\mathrm{ET}_{\mathrm{A}}$ and $\mathrm{ET}_{\mathrm{B}}$ receptors display a diminishing responsiveness to prolonged stimulation (Leite et al., 1994; Khac et al., 1994). In the present study, the single administration of ET-1 showed long-lasting contraction in diabetic as compared to the controls (Fig. 2). Moreover, when stomach fundus strips from control rats were repeatedly exposed to ET-1, marked desensitization was observed (Fig. 3). On the other hand, the stomach fundus strips from diabetic rats showed resistance to desensitization upon repeated ET-1 exposure (Fig. 3). This intergroup difference in the degree of desensitization may be particularly important in the regulation of ET receptor-mediated signaling, since the binding of endothelins to their receptors is essentially irreversible under physiological conditions (Sokolovsky, 1995). Moreover, the rate and extent of desensitization to ET-1 signaling reflects the degree of receptor occupancy (Leite et al., 1994). The fact that two different classes of ET receptors $\left(\mathrm{ET}_{\mathrm{A}}\right.$ and $\left.\mathrm{ET}_{\mathrm{B}}\right)$ are present on gastric muscle cells is attested by several findings (Kitsukawa et al., 1994; Allocock et al., 1995; Mizuguchi et al., 1997). In accord with these previous findings, in the present study ${ }^{125}$ I-labeled ET-1 binding was found to be saturable and specific (Table 2). We showed here that the affinity of ${ }^{125}$ I-labeled ET-1 binding to stomach fundus smooth muscle was similar between the control and diabetic groups. However, the receptor density $\left(B_{\max }\right)$ was significantly increased in the diabetic stomach fundus. Furthermore, the mRNA expression level for the $\mathrm{ET}_{\mathrm{B}}$ receptor was greatly increased in the diabetic stomach fundus (Fig. 4). These results suggest that the enhanced ET-1 contraction and resistance to ET-1 desensitization seen in the STZ-diabetic stomach fundus are attributable to an upregulation of $\mathrm{ET}_{\mathrm{B}}$ receptors. This speculation is in line with the previous finding that $\mathrm{ET}_{\mathrm{B}}$ receptors mediate contraction in rat stomach strips (Allcock et al., 1995), and that upregulated $\mathrm{ET}_{\mathrm{B}}$ receptors were attributed to increased contraction in several arteries (Adner et al., 1996; Henriksson et al., 2003, 2004; Uddman et al., 2003). In gastrointestinal smooth muscle, ET-1 induced an initial transient relaxation followed by a sustained contraction (Allcock et al., 1995; Irie et al., 1995; Chakder and Rattan, 1999). Imaeda et al. (Imaeda et al., 2002) reported that ET1 hyperpolarizes the membrane by activating apamin-sensitive $\mathrm{K}^{+}$channels, mainly as a result of receptor-mediated $\mathrm{Ca}^{2+}$ entry and partly by $\mathrm{Ca}^{2+}$ release from intracellular stores in guinea-pig isolated lower oesophageal sphincter circular smooth muscle. The hyperpolarization triggers the initial transient relaxation, which acts to oppose the sustained contraction (Imaeda $e t a l$., 2002). Although in this study we focus ET-1-induced contractile responses in rat stomach fundus compared with diabetic and control rats, further investigation is required on these points. 
The pathological significance of a diabetes-related enhancement of ET-1-induced contractions in the rat stomach fundus (as observed here in vitro) is unclear. Several reports exist to show that ET-1 affects gastrointestinal function. For instance selective infusion of ET-1 into the gastric artery induced gastric mucosal erosion in the rat (Whittle and Esplugues, 1988), and intravenous infusion of ET-1 exacerbated the damage induced by intragastric instillation of ethanol or acid (Wallace et al., 1989a). Moreover, when injected submucosally into the rat gastric mucosa, ET-1 causes a potent, long-lasting vasoconstriction of the regional microvasculature and induces gastric ulceration (Lazaratos et al., 1993). Taken together, the present evidence of an enhancement of ET-1-induced contractions and of an augmentation of ET-1 signaling in rat stomach fundus strips in STZ-diabetes may be important since such changes may underlie the disruption of gastric transit and the modulation of gastrointestinal function seen in the diabetic state.

In summary, this study has demonstrated an enhanced contraction to ET-1 in strips of gastric fundus from STZ-induced diabetic rats. The results indicate that such enhanced, prolonged contractile responses to ET-1, and their resistance to desensitization, may be due to an upregulation of ET receptors (probably the $\mathrm{ET}_{\mathrm{B}}$ subtype) in the diabetic gastric fundus.

\section{Acknowledgements}

This study was supported in part by the Ministry of Education, Culture, Sports, Science and Technology, Japan, and by the Promotion and Mutual Aid Cooperation for Private Schools of Japan.

\section{References}

Achem-Karam, S.R., Funakoshi, A., Vinik, A.I. and Owyang, C. (1985). Plasma motilin concentration and interdigestive migrating motor complex in diabetic gastroparesis: effect of metoclopramide. Gastroenterol. 88: 492-499.

Adner, M., Cantera, L., Ehlert, F., Nilsson, L. and Edvinsson, L. (1996). Plasticity of contractile endothelin-B receptors in human arteries after organ culture. Br. J. Pharmacol. 119: 1159-1166.

Allcock, G.H., Battistini, B., Fournier, A., Warner, T.D. and Vane, J.R. (1995). Characterization of endothelin receptors mediating mechanical responses to the endothelins in the isolated stomach strips of the rat. J. Pharmacol. Exp. Ther. 275: 120-126.

Bortolotti, M. and Barbara, L. (1988). Interdigestive gastroduodenal motor activity in subjects with increased gastric acid secretion. Digestion 41: 156-160.

Bult, H., Boeckxstaens, G.E., Pelckmans, P.A., Jordaens, F.H., Van Maercke, Y.M. and Herman, A.G. (1990). Nitric oxide as an inhibitory non-adrenergic non-cholinergic neurotransmitter. Nature 345: 346-347.

Bunemann, M. and Hosey, M.M. (1999). G-protein coupled receptor kinases as modulators of G-protein signalling. J. Physiol. (Lond.) 517: 5-23.

Chakder, S. and Rattan, S. (1999). Mechanisms and sites of action of endothelins 1 and 2 on the opossum internal anal sphincter smooth muscle tone in vitro. J. Pharmacol. Exp. Ther. 288: 239-246.

Chomczynski, P. and Sacchi, N. (1987). Single-step method of RNA isolation by acid guanidinium thiocyanate-phenol-chloroform extraction. Anal. Biochem. 162: 156-159.

Feldman, M., Corbett, D.B., Ramsey, E.J., Walsh, J.H. and Richardson, C.T. (1979). Abnormal gastric 
function in longstanding, insulin-dependent diabetic patients. Gastroenterol. 77: 12-17.

Ferguson, S.S. (2001). Evolving concepts in G protein-coupled receptor endocytosis: the role in receptor desensitization and signaling. Pharmacol. Rev. 53: 1-24.

Fox, S. and Behar, J. (1980). Pathogenesis of diabetic gastroparesis: a pharmacologic study. Gastroenterol. 78: 757-763.

Fulginiti, J. 3rd., Cohen, M.M. and Moreland, R.S. (1993). Endothelin differentially affects rat gastric longitudinal and circular smooth muscle. J. Pharmacol. Exp. Ther. 265: 1413-1420.

Goto, K., Hama, H. and Kasuya, Y. (1996). Molecular pharmacology and pathophysiological significance of endothelin. Jpn. J. Pharmacol. 72: 261-290.

Goto, K., Kasuya, Y., Matsuki, N., Takuwa, Y., Kurihara, H., Ishikawa, T., Kimura, S., Yanagisawa, M. and Masaki, T. (1989). Endothelin activates the dihydropyridine-sensitive, voltage-dependent Ca2+ channel in vascular smooth muscle. Proc. Natl. Acad. Sci. U.S.A. 86: 3915-3918.

Gray, G.A., Breu, V. and Clozel, M. (1995). Endothelin receptors that modulate contraction of the rat fundus. J. Cardiovasc. Pharmacol. 26: S126-S129.

Henriksson, M., Stenman, E. and Edvinsson, L. (2003). Intracellular pathways involved in upregulation of vascular endothelin type B receptors in cerebral arteries of the rat. Stroke 34: 1479-1483.

Henriksson, M., Xu, C.B. and Edvinsson, L. (2004). Importance of ERK1/2 in upregulation of endothelin type B receptors in cerebral arteries. Br. J. Pharmacol. 142: 1155-1161.

Holdsworth, C.D. and Besser, G.M. (1968). Influence of gastric emptying-rate and of insulin response on oral glucose tolerance in thyroid disease. Lancet 2: 700-702.

Imaeda, K., Trout, S.J. and Cunnane, T.C. (2002). Mechanical and electrophysiological effects of endothelin-1 on guinea-pig isolated lower oesophageal sphincter circular smooth muscle. Br. J. Pharmacol. 135: 197-205.

Irie, K., Uchida, Y., Fujii, E. and Muraki, T. (1995). Developmental changes in response to endothelins and receptor subtypes of isolated rat duodenum. Eur. J. Pharmacol. 275: 45-51.

Iwamuro, Y., Miwa, S., Minowa, T., Enoki, T., Zhang, X.F., Ishikawa, M., Hashimoto, N. and Masaki, T. (1998). Activation of two types of $\mathrm{Ca}^{2+}$-permeable nonselective cation channel by endothelin- 1 in A7r5 cells. Br. J. Pharmacol. 124: 1541-1549.

Kamata, K., Kohzuki, M., Misawa, M. and Kasuya, Y. (1993). Involvement of nitric oxide pathway in nonadrenergic non-cholinergic (NANC) relaxation in the rat stomach: differential innervation of NANC nerves in the longitudinal and circular muscle of the fundus. Gen. Pharmacol. 24: 14031410.

Kamata, K., Sakamoto, A. and Kasuya, Y. (1988). Similarities between the relaxations induced by vasoactive intestinal peptide and by stimulation of the non-adrenergic non-cholinergic neurons in the rat stomach. Naunyn-Schmiedeberg's. Arch. Pharmacol. 338: 401-406.

Kanie, N. and Kamata, K. (2002). Effects of chronic administration of the novel endothelin antagonist J104132 on endothelial dysfunction in streptozotocin-induced diabetic rat. Br. J. Pharmacol. 135: 1935-1942.

Kanie, N., Matsumoto, T., Kobayashi, T. and Kamata, K. (2003). Relationship between peroxisome proliferator-activated receptors (PPAR $\alpha$ and $\operatorname{PPAR} \gamma$ ) and endothelium-dependent relaxation in streptozotocin-induced diabetic rats. Br. J. Pharmacol. 140: 23-32.

Katz, L.A. and Spiro, H.M. (1966). Gastrointestinal manifestations of diabetes. N. Engl. J. Med. 275: 1350-1361.

Keshavarzian, A., Iber, F.L. and Vaeth, J. (1987). Gastric emptying in patients with insulin-requiring diabetes mellitus. Am. J. Gastroenterol. 82: 29-35.

Khac, L.D., Naze, S. and Harbon, S. (1994). Endothelin receptor type A signals both the accumulation of inositol phosphates and the inhibition of cyclic AMP generation in rat myometrium: stimulation and desensitization. Mol. Pharmacol. 46: 485-494.

Khan, Z.A. and Chakrabarti, S. (2003). Endothelins in chronic diabetic complications. Can. J. Physiol. 
Pharmacol. 81: 622-634.

Kitsukawa, Y., Gu, Z.F., Hildebrand, P. and Jensen, R.T. (1994). Gastric smooth muscle cells possess two classes of endothelin receptors but only one alters contraction. Am. J. Physiol. 266: G713-G721.

Koch, K.L., Stern, R.M., Stewart, W.R. and Vasey, M.W. (1989). Gastric emptying and gastric myoelectrical activity in patients with diabetic gastroparesis: effect of long-term domperidone treatment. Am. J. Gastroenterol. 84: 1069-1075.

Lazaratos, S., Kashimura, H., Nakahara, A., Fukutomi, H., Osuga, T., Urushidani, T., Miyauchi, T. and Goto, K. (1993). Gastric ulcer induced by submucosal injection of ET-1: role of potent vasoconstriction and intraluminal acid. Am. J. Physiol. 265: G491-G498.

Leite, M.F., Page, E. and Ambler, S.K. (1994). Regulation of ANP secretion by endothelin-1 in cultured atrial myocytes: desensitization and receptor subtype. Am. J. Physiol. 267: H2193-H2203.

Lowry, O.H., Rosebrough, N.J., Farr, A.L. and Randall, R.J. (1951). Protein measurement with the Folin phenol reagent. J. Biol. Chem. 193: 265-275.

Makino, A. and Kamata, K. (1998a). Elevated plasma endothelin-1 level in streptozotocin-induced diabetic rats and responsiveness of the mesenteric arterial bed to endothelin-1. $\mathrm{Br}$. J. Pharmacol. 123: 1065-1072.

Makino, A. and Kamata, K. (1998b). Possible modulation by endothelin-1, nitric oxide, prostaglandin $\mathrm{I}_{2}$ and thromboxane $\mathrm{A}_{2}$ of vasoconstriction induced by an $\alpha$-agonist in mesenteric arterial bed from diabetic rats. Diabetologia 41: 1410-1418.

Makino, A. and Kamata, K. (2000). Time-course changes in plasma endothelin-1 and its effects on the mesenteric arterial bed in streptozotocin-induced diabetic rats. Diabetes Obes. Metab. 2: 47-55.

Makino, A., Oda, S. and Kamata, K. (2001). Mechanisms underlying increased release of endothelin-1 from aorta in diabetic rats. Peptides 22: 639-645.

Makino, A. and Kamata, K. (2002). Effects of chronic administration of L-arginine on vasoactive responses induced by endothelin-1 and its plasma level in streptozotocin-induced diabetic rats. J. Smooth Muscle Res. 38: 101-105.

Masaki, T. (2004). Historical review: endothelin. Trends Pharmacol. Sci. 25: 219-224.

Matsumoto, T., Kobayashi, T. and Kamata, K. (2003). Alterations in EDHF-type relaxation and phosphodiesterase activity in mesenteric arteries from diabetic rats. Am. J. Physiol. 285: H283$\mathrm{H} 291$.

Matsumoto, T., Yoshiyama, S., Kobayashi, T. and Kamata, K. (2004a). Mechanisms underlying enhanced contractile response to endothelin-1 in diabetic rat basilar artery. Peptides 25: 1985-1994.

Matsumoto, T., Wakabayashi, K., Kobayashi, T. and Kamata, K. (2004b). Diabetes-related changes in cAMP-dependent protein kinase activity and decrease in relaxation response in rat mesenteric artery. Am. J. Physiol. 287: H1064-H1071.

Mearin, F., Camilleri, M. and Malagelada, J.R. (1986). Pyloric dysfunction in diabetics with recurrent nausea and vomiting. Gastroenterology 90: 1919-1925.

Miyauchi, T. and Masaki, T. (1999). Pathophysiology of endothelin in the cardiovascular system. Annu. Rev. Physiol. 61: 391-415.

Mizuguchi, T., Nishiyama, M., Moroi, K., Tanaka, H., Saito, T., Masuda, Y., Masaki, T., de Wit, D., Yanagisawa, M. and Kimura, S. (1997). Analysis of two pharmacologically predicted endothelin $\mathrm{B}$ receptor subtypes by using the endothelin B receptor gene knockout mouse. Br. J. Pharmacol. 120: 1427-1430.

Ota, S., Hirata, Y., Sugimoto, T., Kohmoto, O., Hata, Y., Yoshimura, K., Nakada, R., Terano, A. and Sugimoto, T. (1991). Endothelin-1 secretion from cultured rabbit gastric epithelial cells. J. Cardiovasc. Pharmacol. 17: S406-S407.

Perri, F., Ghoos, Y.F., Maes, B.D., Geypens, B.J., Ectors, N., Geboes, K., Hiele, M.I. and Rutgeerts, P.J. (1996). Gastric emptying and Helicobacter pylori infection in duodenal ulcer disease. Dig. Dis. Sci. 41: 462-468. 
Rayner, C.K., Samsom, M., Jones, K.L. and Horowitz, M. (2001). Relationships of upper gastrointestinal motor and sensory function with glycemic control. Diabetes Care. 24: 371-381.

Shimomura, A., Itoh, H., Niki, Y., Suga, T., Fujioka, H., Ito, M., Konishi, T., Hollenberg, M.D. and Nakano, T. (1994). Contractile actions of endothelins in rat gastric body: evidence for receptor subtypes and involvement of prostaglandin $\mathrm{E}_{2}$. Eur. J. Pharmacol. 252: 81-86.

Simonson, M.S. and Dunn, M.J. (1990). Cellular signaling by peptides of the endothelin gene family. FASEB J. 4: 2989-3000.

Sokolovsky, M. (1995). Endothelin receptor subtypes and their role in transmembrane signaling mechanisms. Pharmacol. Ther. 68: 435-471.

Takahashi, K., Ghatei, M.A., Lam, H.C., O’Halloran, D.J. and Bloom, S.R. (1990a). Elevated plasma endothelin in patients with diabetes mellitus. Diabetologia 33: 306-310.

Takahashi, K., Jones, P.M., Kanse, S.M., Lam, H.C., Spokes, R.A., Ghatei, M.A. and Bloom, S.R. (1990b). Endothelin in the gastrointestinal tract. Presence of endothelin-like immunoreactivity, endothelin-1 messenger RNA, endothelin receptors, and pharmacological effect. Gastroenterol. 99: 1660-1667.

Tsunoda, K., Abe, K., Sato, T., Yokosawa, S. and Yoshinaga, K. (1991). Decreased conversion of big endothelin-1 to endothelin-1 in patients with diabetes mellitus. Clin. Exp. Pharmacol. Physiol. 8: 731-732.

Uddman, E., Henriksson, M., Eskesen, K. and Edvinsson, L. (2003). Role of mitogen-activated protein kinase in endothelin $\mathrm{ET}_{\mathrm{B}}$ receptor up-regulation after organ culture of rat mesenteric artery. Eur. J. Pharmacol. 482: 39-47.

Ueda, H., Inoue, M. and Matsumoto, T. (2001). Protein kinase C-mediated inhibition of mu-opioid receptor internalization and its involvement in the development of acute tolerance to peripheral mu-agonist analgesia. J. Neurosci. 21: 2967-2973.

Wallace, J.L., Cirino, G., De Nucci, G., Mcknight, W. and MacNaughton, W.K. (1989a). Endothelin has potent ulcerogenic and vasoconstrictor actions in the stomach. Am. J. Physiol. 256: G661-G666.

Wallace, J.L., Keenan, C.M., MacNaughton, W.K. and McKnight, G.W. (1989b). Comparison of the effects of endothelin-1 and endothelin-3 on the rat stomach. Eur. J. Pharmacol. 167: 41-47.

Wang, A.M., Doyle, M.V. and Mark, D.F. (1989). Quantification of mRNA by the polymerase chain reaction. Proc. Natl. Acad. Sci. U.S.A. 86: 9717-9721.

Whittle, B.J. and Esplugues, J.V. (1988). Induction of rat gastric damage by the endothelium-derived peptide, endothelin. Br. J. Pharmacol. 95: 1011-1013.

Yanagisawa, M., Kurihara, H., Kimura, S., Tomobe, Y., Kobayashi, M., Mitsui, Y., Yazaki, Y., Goto, K. and Masaki, T. (1988). A novel potent vasoconstrictor peptide produced by vascular endothelial cells. Nature 332: 411-415.

(Received November 24, 2004; Accepted January 13, 2005) 